\title{
Anchovy larval distribution in the coastal zone off northern Chile: the effect of low dissolved oxygen concentrations and of a cold-warm sequence (1990-95)*
}

\author{
Carmen E. Morales ${ }^{1}$, Mauricio Braun ${ }^{2}$, Hernán Reyes ${ }^{2}$ \\ José L. Blanco ${ }^{2}$ and Anthony G. Davies ${ }^{3}$ \\ ${ }^{1}$ Subsecretaría de Pesca, Casilla 100-V, Valparaíso, Chile \\ ${ }^{2}$ Instituto de Fomento Pesquero (IFOP), Casilla 8-V, Valparaíso, Chile \\ ${ }^{3}$ Marine Biological Association, Plymouth, PL1 2PB, Great Britain
}

\begin{abstract}
This study analyses the patterns of distribution and abundance of anchovy (Engraulis ringens) larvae off northern Chile $\left(18^{\circ}-24^{\circ} \mathrm{S}\right)$, within the coastal zone (out to $100 \mathrm{~nm}$ ) and their relationship to the oceanographic conditions in the top layer (0-200 m depth). The data were derived from surveys undertaken from 1990 to 1995 , during each winter (July-September), the season of the main spawning and higher larval abundance. During the 1995 survey, ichthyoplankton samples were also taken at shallower depths $(<100 \mathrm{~m})$, to assess the influence of low dissolved oxygen concentration upon the vertical distribution of the anchovy larvae.

Both surface temperature and surface salinity distributions revealed that the period of this study covered a sequence from a relatively cold condition (1990) to warmer weak El Niño condition (1992), and back to cooler conditions (1995) in the area. A deepening of the base of the thermocline $\left(15^{\circ} \mathrm{C}\right.$ isotherm) occurred during the warmer period along the whole of the coast. During cooler conditions, the upper boundary of the low dissolved oxygen layer ( $c a .1 .0$ $\mathrm{ml}^{-1}$ ) was found at shallower depths $(<50 \mathrm{~m})$ in most of the northern part of the area (Arica-Iquique) and also the waters above the thermocline were significantly more oxygenated, though variations with depth were greater, than during the warmer periods.

Mean intergrated abundances of anchovy larvae varied significantly between the winter periods of 1990 to 1995 (range: 230-5300 larvae in $10 \mathrm{~m}^{2}$ ), with the highest mean values observed during 1993 and 1994. The highest abundances occurred at the most nearshore stations $(1-5 \mathrm{~nm})$ during all the cruises, though high values were also found at some offshore stations, mainly during the 1993-95 period. The comparison of the mean density of larvae (number $\mathrm{m}^{-3}$ ) over different depth ranges (0-25, 0-50, and/or 0-100 m), suggested the ocurrence of a barrier to their vertical distribution, located in the vicinity of the $0,75 \mathrm{ml} \mathrm{O}_{2} 1^{-1}$ concentration. Overall, the warmer conditions initiated during 1992 appeared to have provided a more suitable environment for the survival and feeding of anchovy larvae in the area, whereas changes in the distribution of low oxygen concentrations did not appear to have a direct influence on larval abundance and distribution.
\end{abstract}

Key words: anchovy larval distribution, low oxygen concentrations, oceanographic conditions, northern Chile.

\section{Distribución de larvas de anchoveta en la zona costera del Norte de Chile: el efecto de bajas concentraciones de oxígeno disuelto y de una secuencia fría-cálida (1990-95)*}

RESUMEN. Este estudio analiza los patrones de distribución y abundancia de larvas de anchoveta (Engraulis ringens) en la zona norte de Chile $\left(18^{\circ}-24^{\circ} \mathrm{S}\right)$, dentro de la zona costera $(0-100 \mathrm{mn})$, y su relación con las condiciones oceanográficas en la capa superior (0-200 $\mathrm{m}$ de profundidad). Los datos utilizados se derivaron de cruceros realizados entre 1990 y 1995, durante cada invierno (julio-septiembre), la época de desove principal y de mayor abundancia de larvas. Durante el crucero de invierno de 1995 se realizó, además, un muestreo adicional con arrastres verticales a profundidades menores $(<100 \mathrm{~m})$ para analizar el efecto de la concentración de oxígeno sobre la distribución vertical de las larvas de anchoveta.

\footnotetext{
* Proyecto FONDECYT N 1950043, 1995.
} 
Las distribuciones superficiales de temperatura y salinidad indicaron que este estudio cubrió una secuencia de condiciones normales frías (1990) a cálidas tipo El Niño (1992), y luego un retorno a condiciones frías (1995). Durante el período cálido, la base de la termoclina (isoterma de $15^{\circ} \mathrm{C}$ ) se profundizó notoriamente a lo largo de toda la costa. Durante las condiciones frías, el límite superior de la capa de mínimo oxígeno ( $\left.c a .1 .0 \mathrm{ml} \mathrm{1}^{-1}\right)$ se localizó a baja profundidad $(<50 \mathrm{~m})$ en la parte norte del área de estudio (Arica-Iquique) y las aguas sobre la termoclina estuvieron significativamente más oxigenadas, aunque el cambio con la profundidad fue mayor, que en los períodos cálidos.

La abundancia promedio integrada de larvas de anchoveta fue significativamente diferente durante el período invierno 1990 - invierno 1995 (rango: 230-5300 larvas en $10 \mathrm{~m}^{2}$ ), con los mayores valores de abundancia observados durante 1993 y 1994. Las mayores abundancias se presentaron en las estaciones más costeras (1-5 mn) durante todos los cruceros, aunque valores altos también ocurrieron en las estaciones oceánicas, especialmente durante el período 1993-95. La comparación de las densidades promedios (larvas $\mathrm{m}^{-3}$ ), entre las diferentes profundidades muestreadas ( 0 25, 0-50 y/o 0-100 m), sugiere la ocurrencia de una barrera a las distribución vertical de las larvas de anchoveta, localizada en las proximidades de concentraciones de oxígeno de $0,75 \mathrm{ml} \mathrm{1}^{-1}$. Las condiciones cálidas iniciadas durante 1992 parecen haber proporcionado un ambiente más favorable para la sobrevivencia y alimentación de las larvas de anchoveta en el área, sin embargo, los cambios en la distribución de bajas concentraciones de oxígeno durante el período de estudio no parecen haber tenido una influencia directa sobre las variaciones en la abundancia y distribución de estas larvas.

Palabras claves: distribución de larvas de anchoveta, bajas concentraciones de oxígeno, condiciones oceanográficas, zona norte de Chile.

\section{INTRODUCTION}

The Chile-Peru Current System off South America (or Humboldt Current System) is, on a global basis, one of the most productive eastern boundary currents, with an extensive upwelling region which supports one of the largest pelagic fisheries in the world (Hutchings, 1992). The main component of these fisheries are the small pelagic clupeids, anchovy (Engraulis ringens) and sardine (Sardinops sagax), which exhibit extreme population fluctuations (Santander \& Flores, 1983; Serra, 1983; Yáñez, 1989; Alheit \& Bernal, 1993). The fluctuations and the alternation in the dominance of these species, as well as those in clupeid populations of other eastern boundary currents, are believed to be largely driven, besides fishing pressure, by short and long term/scale variations in atmospheric and oceanographic conditions; these are usually reflected by sea surface temperature distribution and dominated by sequences of cold and warm (El Niño) events of varying intensity and duration (Loeb \& Rojas, 1988; Kawasaki, 1991; Yañez, 1991; LluchBelda et al., 1992; Alheit \& Bernal, 1993).

Unlike the other eastern boundary currents, the Humboldt system presents an extensive oxygen minimum layer with an upper boundary of low concentrations ( $c a .1 .0 \mathrm{ml} \mathrm{O}_{2} 1^{-1}$ ) close to the surface ( $<100 \mathrm{~m}$ depth) within most of the coastal zone. These low dissolved oxygen $\left(\mathrm{DO}_{2}\right)$ concentrations are associated with the Equatorial Subsurface water mass (Sievers \& Silva, 1982; Silva, 1983), a frequent source of coastal upwelling water in the region (Robles et al., 1976); Morales et al., 1996). In the region off Peru, the iso-oxyline of $0.5 \mathrm{ml}^{-1}$ has been reported to be correlated with the $15^{\circ} \mathrm{C}$ isotherm (Santander et al., 1981) and these values represent, repectively, the oxycline and the thermocline, and usually establish the limit of the euphotic zone (Richman \& Smith, 1981). Within the coastal zone off northern Chile, low concentrations of dissolved oxygen (in the range of $0.25-0.50 \mathrm{ml} \mathrm{1}^{-1}$ ) occur within the top $100 \mathrm{~m}$ layer (IFOP, unpublished reports). Moreover, there is usually a sharp change in $\mathrm{DO}_{2}$ concentrations with depth within this layer and some of the iso-oxylines bend upwards to the surface in the nearshore zone, in association with coastal upwelling events (Morales et al., 1996).

Dissolved oxygen concentrations and temperature have both been suggested as factors defining the potentially inhabited volume of clupeids in the Chile-Peru Current System (Jarre et al., 1991), whereas only temperature has been considered important in other eastern boundary regions (Le Clus, 1991; Lluch-Belda et al., 1991). Temperature tolerance limits of $14^{\circ}-21^{\circ} \mathrm{C}$ and of $16^{\circ}-23^{\circ} \mathrm{C}$ and oxygen tolerance limits of $1.8 \mathrm{ml}^{-1}$ and of $2.0 \mathrm{ml}$ $1^{-1}$, for respectively anchovy and sardine, have been described for this region, the two factors usually being closely related (Jarre et al., 1991). In the area off northern Chile, anchovy stocks have been 
reported to be constrained by a temperature range of $12^{\circ}-18^{\circ} \mathrm{C}$ during the wintertime, as assessed from a series of cruises (IFOP, unpublished reports). The impact of these factors on their larvae and egg abundance and distribution has not been assessed though the evidence from the coastal waters off Peru indicates that the vertical distribution of the larvae is limited to the surface $30 \mathrm{~m}$ (Sameoto, 1981). Ichthyoplankton surveys off northern Chile have traditionally used a standard integrating depth range of $0-100 \mathrm{~m}$ (or the depth of the water column in shallower areas) for hauls undertaken to provide estimates of clupeid eggs and larvae abundances (IFOP, unpublished reports).

If the clupeid larvae inhabiting the Chile-Peru region do not tolerate low $\mathrm{DO}_{2}$ concentrations or low temperatures in the water column, their potentially inhabited volume could be constrained to shallow waters $(<100 \mathrm{~m})$. This would imply that larval density (as numbers per $\mathrm{m}^{3}$ ) may be significantly underestimated when using a standard $100 \mathrm{~m}$ sampling depth. The vertical distribution of fish larvae remains a poorly studied subject, being usually regarded as an irrelevant detail and an unwanted source of sampling error in most fisheries monitoring programmes. The vertical patterns of fish larvae distribution might, however, reflect the factors that are controlling recruitment processes and, therefore, affecting the fisheries of a given resource (Bakun, 1989). Because of the peculiar characteristics of the Chile-Peru Current System with regard to the $\mathrm{DO}_{2}$ distribution, studies of the factors that might limit clupeid larvae distribution and/or influence their abundances are thus highly relevant.

Off northern Chile, the clupeids contribute significantly to the pelagic fisheries of the region (SERNAP, 1994) and the area constitutes an important spawning centre and nursery ground for both anchovy and sardine, the austral winter being the season of the main spawning and of higher larval abundance (Bernal et al., 1982; Loeb \& Rojas, 1988). Although there is an important historical set of data for this region obtained from several field surveys (IFOP, unpublished reports), there have been only a few published studies relating the oceanographic conditions to the distribution of the clupeids (Yañez et al., 1995) and/or their eggs and larvae (Bernal et al., 1982; Loeb \& Rojas, 1988).
The aim of the present study was to understand the influence of oceanographic conditions upon the distribution and abundance of clupeid larvae in the coastal zone off northern Chile ( $c a .18^{\circ}$ to $\left.24^{\circ} \mathrm{S}\right)$, analysing data collected during IFOP winter cruises (July-September), during the $1990-95$ period. In the two years prior to this period, the Southern Oscillation Index (SOI) showed the ocurrence of a cold event; this was followed by a gradual warming which reached a maximum at the beginning of 1992 and persisted, at weak intensity, until mid-1994. After this, the SOI revealed a reversion to normal (1995), then cooler (1996) conditions (BAC, 1996).

Preliminary analyses of the IFOP data set showed that the sardine larvae occurred rather infrequently during the 1990-95 period; the focus of the present study was, thus, on anchovy larvae abundance. The objectives were: a) to describe and analyse the oceanographic conditions (temperature, salinity, and $\mathrm{DO}_{2}$ concentration) in the surface layer $(0-200 \mathrm{~m})$ during the 1990-95 winter period, and their association with the distribution and abundance of anchovy larvae, and b) to evaluate the effect of low $\mathrm{DO}_{2}$ concentrations as a factor limiting the vertical distribution of anchovy larvae and to assess its implications in the analysis of the interannual variability in their abundances.

\section{MATERIALS AND METHODS}

\section{Area of study and sampling design}

The pelagic resources off northern Chile have, for several years, been the subject of multiple IFOP surveys, which included ichthyoplankton sampling and oceanographic data gathering. For the purposes of this study, the data from the following six cruises were selected and considered to be representative of winter conditions in the area: 1990 (July- August), 1991 (August), 1992 (September), 1993, 1994, and 1995 (August-September). The winter season in this area lasts from mid-June to mid-September; a distinctive feature of this season is that the surface temperature shows only weak negative inshore gradients $\left(<3^{\circ} \mathrm{C}\right)$, suggesting lower upwelling activity, in contrast to the rest of the year when gradients are more marked and temperatures within most of the oceanic sector exceed $18^{\circ} \mathrm{C}$ (IFOP, unpublished reports). 
Each cruise consisted of between 14 and 19 transects, perpendicular to the coast and separated by $c a$. 20 or 25 nautical miles $(\mathrm{nm})$, in the area between $\mathrm{ca}$. $18^{\circ}$ and $24^{\circ} \mathrm{S}$ (Fig. 1). Within each transect, ichthyoplankton sampling stations were usually located at ca. 1.5, 10, 20, 40, 70, and 100 $\mathrm{nm}$ from the coast. At most of these stations, oceanograhic samples were taken with Niskin bottles and/or CTD casts (conductivity, temperature and $\mathrm{DO}_{2}$ sensors) to determine temperature and salinity distributions within the top layer (0-200 m depth). $\mathrm{DO}_{2}$ concentrations were also determined chemically at more than a half of these stations.

Ichthyoplankton samples were obtained from vertical tows, using a WP2 $(300 \mu \mathrm{m})$ net and a calibrated TSK-flowmeter, integrating over the 0$100 \mathrm{~m}$ depth or down to near the bottom at shallower stations. The samples were fixed (4\% buffered formalin) on board and stored until further analysis in the laboratory. To investigate the effect of low $\mathrm{DO}_{2}$ concentrations in limiting the vertical distribution of anchovy larvae in the area, a series of additional ichthyoplankton samples were taken during the winter cruise of 1995. These samples were obtained at a smaller set of stations, selecting one or two depth strata shallower than the standard 100 $\mathrm{m}$ sample. Because of cruise-time and CTDgraphical limitations for identifying, at each station, the depth strata needed to be sampled, these depths were fixed, based on a preliminary analysis of the $\mathrm{DO}_{2}$ concentration data available for the 1990-94 period (IFOP, unpublished reports). The sampling design consisted of three depth strata (0-25, 0-50, and $0-100 \mathrm{~m}$ ) for the most inshore stations $(1,5,10$ and $20 \mathrm{~nm}$ stations), and two depth strata (0-50 and 0-100 m) for the outer stations (40, 70 and $100 \mathrm{~nm})$. A total of 62 stations were completed, and 152 ichthyoplankton samples were obtained.

\section{Data analysis}

The oceanographic data gathered during the 199095 IFOP cruises off northern Chile have been previously reported as continuous measurements of temperature, salinity and $\mathrm{DO}_{2}$, using calibrations derived from discrete measurements (IFOP, unpublished reports). The analyses of these data focussed on the year-to-year variability in the distribution of the oceanographic variables at the surface and within the top $200 \mathrm{~m}$ depth. The identification and counting of anchovy larvae was carried out by microscopy, analysing the whole sample. Abundances were estimated using the standard procedures for ichthyoplankton samples (Smith \& Richardson, 1979). Vertically integrated abundance estimates of larvae (numbers per $10 \mathrm{~m}^{2}$ ) were used to compare their horizontal distribution within the area of study, with emphasis on the variability between years and with distance from the coast.

The ichthyoplankton abundance data derived from the stratified sampling of 1995 were compared in terms of density of larvae (number $\mathrm{m}^{-3}$ ) in the different depth ranges. To test the influence of low $\mathrm{DO}_{2}$ concentration on the vertical distribution of anchovy larvae, the same set of data was analysed on the basis that the ratio of the average abundance of the larvae in the $0-50 \mathrm{~m}$ range $(\mathrm{B})$ to that in the 0 $25 \mathrm{~m}$ range (A) should only be greater than 0.5 if the barrier to vertical movement was below $25 \mathrm{~m}$. The corresponding ratio of the data for the $0-100 \mathrm{~m}$ range $(\mathrm{C})$ to that for the $0-50 \mathrm{~m}$ range $(\mathrm{B})$ should, similarly, only exceed 0.5 if the barrier was below $50 \mathrm{~m}$.

To obtain an estimate of the highest $\mathrm{DO}_{2}$ concentration limiting the vertical movement of anchovy larvae, it was necessary to identify which iso-oxyline lay at depths greater than $25 \mathrm{~m}$ for all the stations where the abundance ratio $\mathrm{B} / \mathrm{A}$ exceeded 0.5 and depths greater than $50 \mathrm{~m}$ for the stations where the abundance ratio $\mathrm{C} / \mathrm{B}$ exceeded 0.5 . For this purpose, the ratios between paired depth ranges were graphically analysed by plotting them against the depth of the potentially limiting concentrations $\left(2.0,1.0\right.$ and $\left.0.75 \mathrm{ml} \mathrm{O}_{2} \mathrm{1}^{-1}\right)$ at the same station. With this as a basis, a qualitative comparison between the abundances of anchovy larvae in the different depth ranges was made, considering the location of the identified limiting $\mathrm{DO}_{2}$ concentration. These results were used to compare the abundances and distributions of these larvae during the 1990-95 winter period in relation to the variations in the oceanographic conditions, in particular, the variations in the distribution of $\mathrm{DO}_{2}$ concentrations.

\section{RESULTS}

\section{Oceanographic conditions within the top layer off northern Chile: 1990-95 winter period}

The distribution of surface temperature (Fig. 2) during the winter of 1990 was relatively 

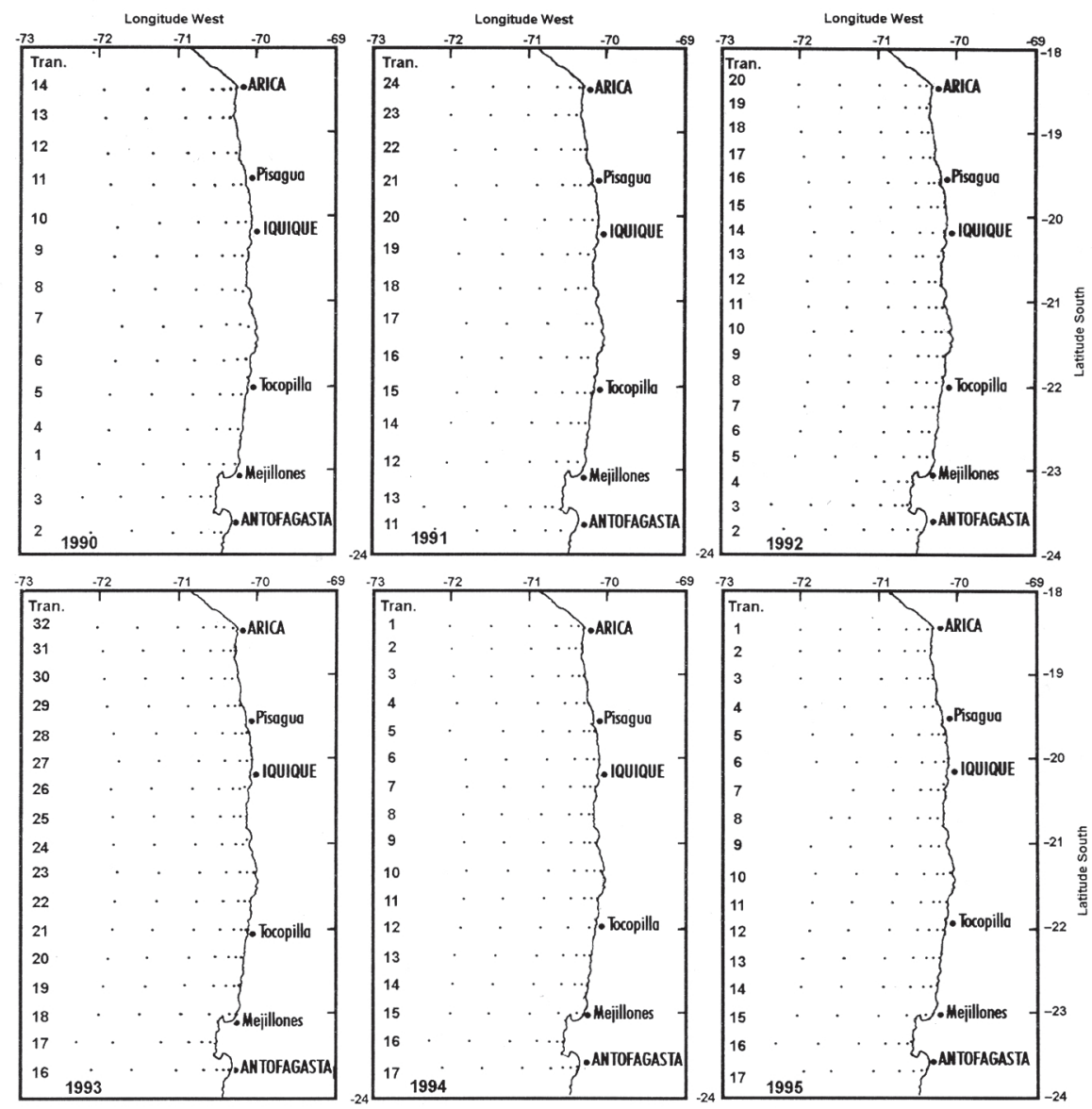

Figure 1. Area of study off northern Chile, with position of the stations and transect (Tran) numbers for the ichthyoplankton cruises carried out during the winters of 1990 to 1995.

Figura 1. Area de estudio en la zona norte de Chile, con la posición de las estaciones y números de transecta (Tran) para los cruceros de ictioplancton ejecutados durante los inviernos de 1990 a 1995.

homogeneous in the area $\left(\mathrm{ca} .15^{\circ}\right.$ to $\left.<17^{\circ} \mathrm{C}\right)$ but a gradual warming started during the winter of 1991 , reaching a maximum during the 1992-93 winters. This event affected mainly the northern (AricaIquique) and central sectors (Iquique-Tocopilla), resulting in a south to north difference of $c a .4^{\circ} \mathrm{C}$ $\left(15^{\circ}\right.$ to $\left.<19^{\circ} \mathrm{C}\right)$ within the study area. During the winter of 1994, the range of surface temperatures returned to a more homogeneous condition $\left(\mathrm{ca} .16^{\circ}\right.$ to $<18^{\circ} \mathrm{C}$ ), though warmer than during the winter of 1990. Surface temperature distribution during the winter of 1995 indicated a further cooling and the lowest values of the period $\left(<15^{\circ} \mathrm{C}\right)$ were reached in most of the southern part (Tocopilla-Antofagasta). An analysis of the temperature anomalies, using historical values (IFOP, unpublished reports), indicated similarities between the winters of 1990 , 1991 and 1995 (values of $c a .0^{\circ} \mathrm{C}$ ), whereas during the winters of 1992 and 1993, the anomalies were positive (values $>1{ }^{\circ} \mathrm{C}$ ) in the northern and central parts of the area. The winter of 1994 presented an intermediate condition, with smaller nuclei of positive anomalies $\left(>1^{\circ} \mathrm{C}\right)$ both in the north and the south of the study area.

The distributions of surface salinity (Fig. 3) during the winters of 1990, 1991, and 1995 were similar in that the values were within the lower part of the range ( $>34,6$ to $<35,0 \mathrm{psu}$ ); this indicated the predominance of subantarctic waters in the area. Furthermore, the winters of 1991 and 1995 were 

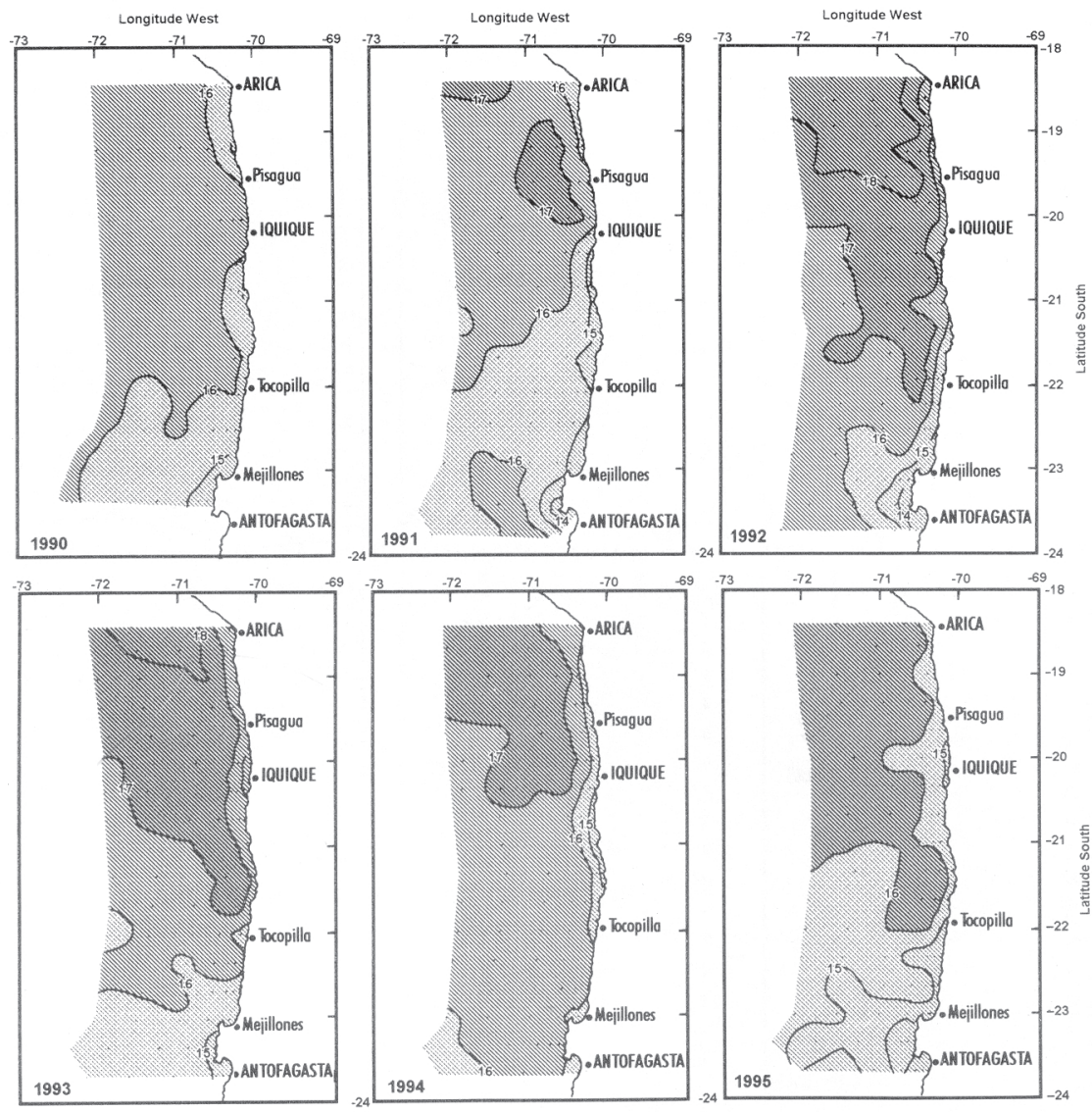

Figure 2. Distribution of surface temperature off northern Chile during the 1990-95 winter cruises.

Figura 2. Distribución de temperatura superficial en la zona norte de Chile durante los cruceros de invierno de 1990-95.

similar in that the lowest values of the range were found in the southern part; during the winter of 1990 , the salinity values were higher. The range of surface salinity values found during the 1992-1994 period was higher ( $>34,8$ to $35,3 \mathrm{psu}$ ), suggesting that waters of subtropical origin were then prevalent in the northern and central parts of the area. A characteristic of the winter of 1993, however, was the ocurrence of a high salinity front in the southern part, so that the whole of the area was under the influence of more saline water masses.

The depth of the $15^{\circ} \mathrm{C}$ isotherm (Fig. 4), frequently assumed to represent the base of the thermocline in the coastal zone of this region (Richman \& Smith, 1981; Blanco \& Díaz, 1985), corroborate a sequence from cooler to warmer and then back to cooler conditions between the winter of 1990 and the winter of 1995. During the warmer winters (1992 and 1993), there was a deepening of the thermocline, with depths of $40 \mathrm{~m}$ being restricted to the most nearshore zone ( $<20 \mathrm{~nm}$ from the coast). This situation constrasted with the winters of 1990 and 1995, when the $40 \mathrm{~m}$ depth distribution of the $15^{\circ} \mathrm{C}$ isotherm extended to the offshore zone ( $>40$ $\mathrm{mm}$ from the coast), remarkably so during the winter of 1995. The winters of 1991 and 1994 presented an intermediate situation between those above.

The distribution of $\mathrm{DO}_{2}$ concentrations in the water column (0-200 $\mathrm{m}$ depth) was analysed in terms of the depth of $1.0 \mathrm{ml} \mathrm{O}_{2} 1^{-1}$ concentration, a priori selected as being a potentially limiting concentration for the vertical distribution of anchovy larvae and also being characteristic of the nucleus of the Equatorial Subsurface water mass (Silva, 1983). 

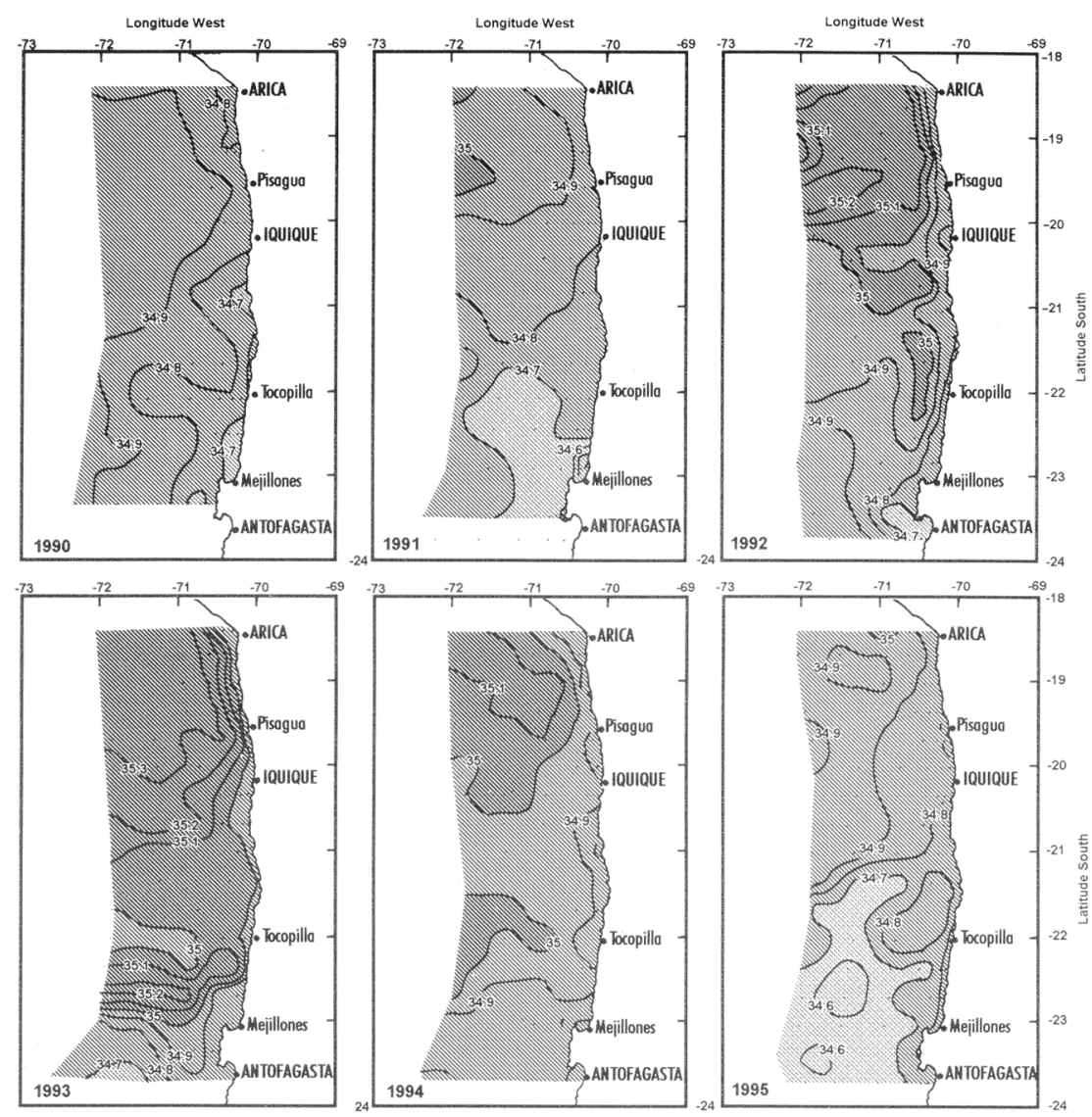

Figure 3. Distribution of surface salinity off northern Chile during the winters of 1990-95 winter cruises.

Figura 3. Distribución de salinidades superficiales en la zona norte de Chile durante los cruceros de invierno de 1990-95.

During the years 1990, 1991, 1994 and 1995 (Fig. 5), a concentration of $1.0 \mathrm{ml} \mathrm{O}_{2} \mathrm{l}^{-1}$ ocurred at shallower depths $(<50 \mathrm{~m})$ further offshore in the northern part of the study area than during the warmer winters (1992-93), when it was restricted to the most nearshore zone ( $<20 \mathrm{~nm}$ from the coast) in the whole of the area. Depths close to or greater than $100 \mathrm{~m}$ for the $1.0 \mathrm{ml} \mathrm{O}_{2} 1^{-1}$ concentration were observed mainly in the southern offshore zone; during the 1991 winter, however, this feature also appeared closer to the coast in the central part of the area (off Iquique).

The relationship between temperature and $\mathrm{DO}_{2}$ concentrations in the water column (top $200 \mathrm{~m}$ depth), for each of the winter cruises, were assessed through linear regression analyses (least squares). The results (Table 1) showed that both variables were significantly linearly correlated $(\mathrm{p}<0.001)$, all the regressions having relatively high coefficients of determination $\left(R^{2}>0.67\right)$. The regressions for all of the data from each cruise (1-100nm) were compared with those for just the nearshore stations $(1-20 \mathrm{~nm})$ in order to remove the potential differences in structure between the upwelling zone and the oceanic waters (Table 1). To summarise these results, all data from the different cruises were combined to provide the total regressions of each group (standard error of coefficients in parenthesis):

$\mathrm{DO}_{2}\left(\mathrm{ml} \mathrm{1}^{-1}\right)=-15.11(0.13)+1.24(0.01)$ Temperature $\left({ }^{\circ} \mathrm{C}\right)$ $\left(\mathrm{R}^{2}=0.74 ; \mathrm{n}=6625\right) \quad($ data: $1-100 \mathrm{~nm})$

$\mathrm{DO}_{2}\left(\mathrm{ml} \mathrm{l}^{-1}\right)=-15.84(0.18)+1.28(0.01)$ Temperature $\left({ }^{\circ} \mathrm{C}\right)$ $\left(\mathrm{R}^{2}=0.74 ; \mathrm{n}=3383\right) \quad$ (data: $\left.1-20 \mathrm{~nm}\right)$ 
Table 1. Temperature $\left({ }^{\circ} \mathrm{C}\right)$ and dissolved oxygen $\left(\mathrm{DO}_{2}\right)$ relationship during the period of study (winters 1990 95). Linear regression analyses for all the stations (ca. 1 to $100 \mathrm{~nm})$ and for the nearshore stations (ca. 1 to 20 $\mathrm{nm})$. Columns 6 and 7 give predictions for $\mathrm{DO}_{2}$ concentration at the base of the thermocline $\left(15^{\circ} \mathrm{C}\right)$ and for the temperature at the upper boundary of the oxygen minimum layer $\left(1 \mathrm{ml} \mathrm{l}^{-1}\right)$, respectively. $N=$ number of samples; $\mathbf{R}^{2}=$ coefficient of determination.

Tabla 1. Relación entre temperatura $\left({ }^{\circ} \mathrm{C}\right)$ y oxígeno disuelto $\left(\mathrm{DO}_{2}\right)$ durante el período de estudio (inviernos de 1990-95). Análisis de regresión lineal para todas las estaciones (ca. 1 a $100 \mathrm{mn}$ ) y para las estaciones costeras (ca. 1 a $20 \mathrm{mn}$ ). Las columnas 6 y 7 proporcionan predicciones sobre la concentración de $\mathrm{DO}_{2}$ en la base de la termoclina $\left(15^{\circ} \mathrm{C}\right)$ y sobre la temperatura en el borde superior de la capa de mínimo oxígeno $\left(1 \mathrm{ml}^{-1}\right)$, respectivamente. $\mathbf{N}=$ número de muestras; $\mathbf{R}^{2}=$ coeficiente de determinación.

\begin{tabular}{|l|rlcrrr|}
\hline Year & \multicolumn{1}{|c}{$\mathrm{N}$} & Intercept & Slope & $\mathrm{R} 2$ & DO2(ml l-1) & ${ }^{\circ} \mathrm{C}$ \\
\hline All stations & & & & & & \\
1990 & 888 & $-16,10$ & 1,35 & 0,86 & 4,15 & 12,67 \\
1991 & 1050 & $-15,86$ & 1,29 & 0,79 & 3,49 & 13,07 \\
1992 & 728 & $-13,50$ & 1,12 & 0,85 & 3,30 & 12,95 \\
1993 & 1128 & $-13,61$ & 1,11 & 0,67 & 3,04 & 13,16 \\
1994 & 1110 & $-16,07$ & 1,28 & 0,79 & 3,13 & 13,34 \\
1995 & 1721 & $-18,84$ & 1,53 & 0,74 & 4,11 & 12,97 \\
Nearshore stations & & & & & & \\
1990 & 447 & $-17,45$ & 1,45 & 0,82 & 4,30 & 12,72 \\
1991 & 492 & $-16,11$ & 1,30 & 0,78 & 3,39 & 13,16 \\
1992 & 343 & $-13,43$ & 1,10 & 0,88 & 2,92 & 13,24 \\
1993 & 620 & $-14,99$ & 1,20 & 0,71 & 3,01 & 13,33 \\
1994 & 569 & $-18,13$ & 1,43 & 0,82 & 3,32 & 13,38 \\
1995 & 911 & $-19,12$ & 1,54 & 0,74 & 3,98 & 13,06 \\
\hline
\end{tabular}

Although the slopes and elevations of these regressions were significantly different (Student's $\mathrm{t} ; \mathrm{p}<0.05)$, they involved a difference of only $0.1 \mathrm{ml}$ $\mathrm{O}_{2} \mathrm{ml} \mathrm{l}^{-1}$ between the estimates. On the other hand, both groups of data showed the same tendency of differences between cruises, separating the colder winters $(1990,1995)$ from the warmer winters (1992, 1993), with transitional winters in between (1991, 1994). A comparison of the regressions for all the data from each cruise (covariance analyses), both for slopes and elevations, resulted in significant differences between these three periods $(\mathrm{p}<0.05)$. The regressions for the winters of 1990 and 1995 were also significantly different but the slopes of both were still higher than those of the transitional and the warmer winters.

In order to separate the potential effects of these two closely related factors, the regression equations for each of the cruises (Table 1) were used to estimate the $\mathrm{DO}_{2}$ concentrations at the base of the thermocline $\left(15^{\circ} \mathrm{C}\right)$ and the temperature at the $\mathrm{DO}_{2}$ concentration representing the upper boundary of the minimum oxygen layer $\left(1.0 \mathrm{ml} \mathrm{l}^{-1}\right)$. This analysis indicated that these potential barriers do not coincide in depth, the base of the thermocline being shallower than is the minimum oxygen concentration. Thus, even though temperature and oxygen are strongly related, this shows that if the base of the thermocline represented the main barrier to the vertical movement of the anchovy larvae, $\mathrm{DO}_{2}$ concentrations of between 3.0 and $4.0 \mathrm{ml} \mathrm{O}_{2} \mathrm{l}^{-1}$ would be present at this barrier. On the other hand, if the distribution of the larvae was mainly restricted by an oxygen minimum layer, this would imply that the larvae would be able to tolerate temperatures as low as $c a .13^{\circ} \mathrm{C}$. Also, the estimates revealed that, between the warmer and colder periods, there was a $1.0 \mathrm{ml} \mathrm{O}_{2} \mathrm{1}^{-1}$ difference in the $\mathrm{DO}_{2}$ concentrations at the base of the thermocline $\left(15^{\circ} \mathrm{C}\right)$, the waters above the thermocline being 

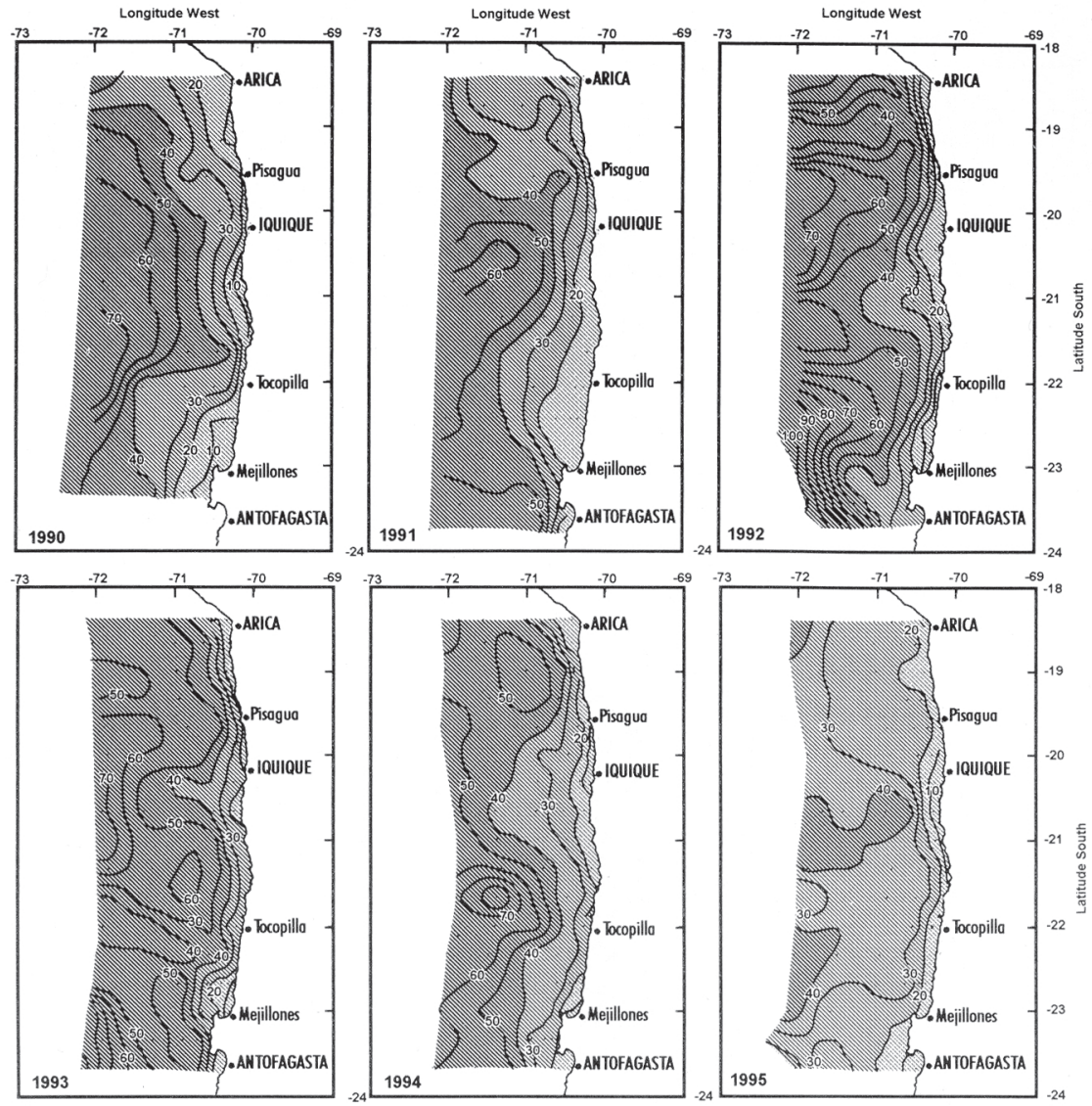

Figure 4. Depths of the thermocline $\left(15^{\circ} \mathrm{C}\right.$ isotherm) off northern Chile during the $1990-95$ winter cruises.

Figura 4. Profundidades de la termoclina (isoterma de $15^{\circ} \mathrm{C}$ ) en la zona norte de Chile durante los cruceros de invierno de 1990-95.

significantly more oxygenated, though with greater variations in depth, during cooler conditions.

Overall, the distributions of surface temperature and surface salinity during the winters of 1990 to 1995 suggested a sequence from cooler (1990) to warmer (1992-93) and back to cooler (1995) conditions. These distributions indicated a northward extension of the subantarctic water mass during the cooler years, and a southwardth extension of the subtropical water during the warmer years; intermediate conditions of west-east water mass movements were also observed, especially during the winter of 1993. The distribution of the $1.0 \mathrm{ml} \mathrm{O}_{2}$ $\mathrm{I}^{-1}$ concentration in the water column suggested that the Equatorial Subsurface water mass, which flows mainly poleward, was deepened by the presence of the subtropical waters while the reverse ocurred during the cooler winters, mainly in the northern part of the study area.

Abundance and distribution of anchovy larvae off northern Chile in relation to the oceanographic conditions: 1990-1995 winter period.

The mean integrated abundance (number per $10 \mathrm{~m}^{2}$ ) of anchovy larvae (Table 2) was significantly lower during 1991 as compared with the moderate abundances during 1990, 1992 and 1995, while those during 1993 and, especially during 1994, were significantly higher $(\mathrm{p}<0.001)$. Because of the large coefficient of variation for each year (ca. 200\%), the median of these values was also calculated, the results showing the same tendency (Table 2). Overall, the anchovy larvae abundances over the 

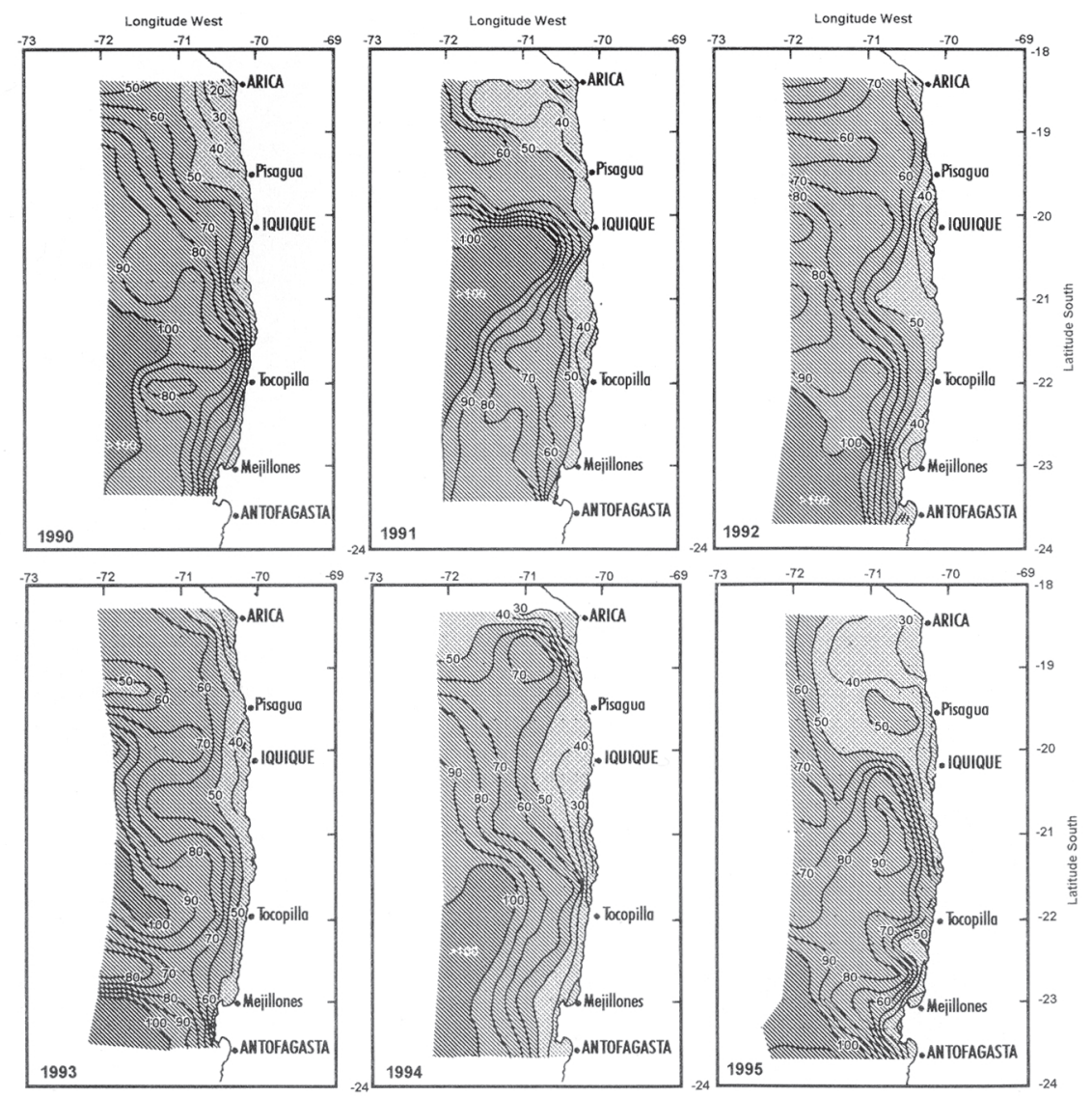

Figure 5. Depths of the $1.0 \mathrm{ml}^{-1}$ dissolved oxygen concentration off northern Chile during the 1990-95 winter cruises.

Figura 5. Profundidades de la concentración de oxígeno disuelto de $1.0 \mathrm{ml} \mathrm{l}^{-1}$ en la zona norte de Chile durante los cruceros de invierno de 1990-95.

whole of the area were lower during both colder (1990, 1995) and warmer winters (1992) but increased significantly during the two winters following the warming conditions of 1992.

The horizontal distribution and abundance of anchovy larvae analysed in relation to distance from the coast $(0-100 \mathrm{~nm})$, during the winters of 1990 to 1995 (Fig. 6) suggested a tendency for an aggregation of the higher abundance values within the first $5 \mathrm{~nm}$ from the coast. A statistical comparison (Kruskal-Wallis analysis of variance), pooling the data from the different years, indicated that the abundances of larvae at the most nearshore stations ( 1 and $5 \mathrm{~nm}$ from the coast) were significantly higher than those at the stations further offshore, independently of considering all the stations $(\mathrm{n}=681) ; \mathrm{p}<0.001)$ or only those in which anchovy larvae were present $(\mathrm{n}=557, \mathrm{p}<0.001)$. The same analysis for each year treated separately showed that, of the six winters, only during 1995 there was a significant increase in the abundance at the 70 and $100 \mathrm{~nm}$ stations; the abundance values for these stations were then similar to those in the nearshore stations $(\mathrm{p}<0.05)$, when considering all the stations or just those in which the larvae were present. The same set of data (Fig. 6) indicated that there was both an offshore and a latitudinal extension in the distribution of anchovy larvae during the winters of 1993 and 1994, with high abundances (>5000 larvae per $10 \mathrm{~m}^{2}$ ) located further offshore than during the remaining years. On the other hand, the highest abundance values during each winter of the 1990- 

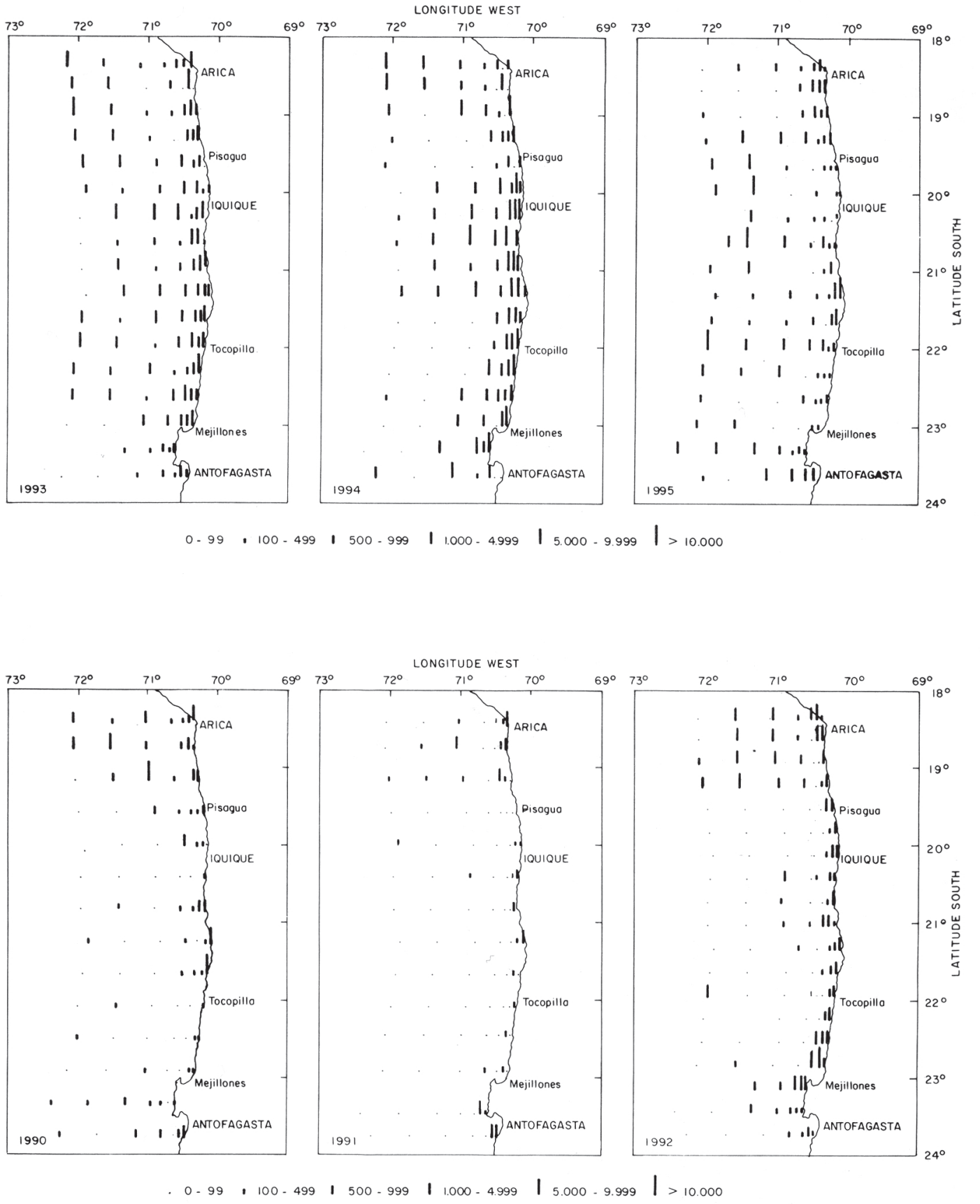

Figure 6. Integrated abundances of anchovy larvae (number $10 \mathrm{~m}^{-2}$ ) off northern Chile during 1990-95 winter cruises.

Figura 6. Abundancias integradas de larvas de anchoveta (number $10 \mathrm{~m}^{-2}$ ) en la zona norte de Chile durante los cruceros de invierno de 1990-95. 
Table 2. Integrated abundance of anchovy larvae (number $10 \mathrm{~m}^{-2}, 0-100 \mathrm{~m}$ ) off northern Chile during the winters 1990-95. $\mathrm{N}=$ number of samples; MEAN=mean of total number of stations; $\mathrm{SD}=$ one standard deviation.

Tabla 2. Abundancia integrada de larvas de anchoveta (número $10 \mathrm{~m}^{-2}, 0-100 \mathrm{~m}$ ) en la zona norte de Chile durante los inviernos de 1990-95. N=número de muestras; MEAN=promedio del número total de estaciones; $\mathrm{SD}=$ desviación estándar.

\begin{tabular}{|c|ccccc|}
\hline Year & N & Mean & SD & Median & Range \\
\hline 1990 & 98 & 969 & 3286 & 150 & $0-27647$ \\
1991 & 98 & 228 & 536 & 22 & $0-3415$ \\
1992 & 131 & 893 & 1821 & 170 & $0-15066$ \\
1993 & 119 & 2318 & 2564 & 1483 & $0-15044$ \\
1994 & 119 & 5346 & 10411 & 2354 & $0-91626$ \\
1995 & 116 & 1444 & 2766 & 474 & $0-15447$ \\
\hline
\end{tabular}

95 period were repeatedly located neashore off Arica (ca. 18 30'S) and off the Loa river (stream), between Iquique and Tocopilla (ca. $21^{\circ} 30^{\prime} \mathrm{S}$ ).

The results of the vertical net hauls in the three depth ranges sampled during the 1995 winter cruise, expressed as the abundance or density of anchovy larvae (number $\mathrm{m}^{-3}$ ) are summarised in Table 3, together with other relevant data. A comparison of the abundances of larvae in two depth ranges for each station sampled (Wilcoxon paired-sample ttest) showed that they were significantly higher $(\mathrm{p}<0.05)$ in the shallower ranges $(0-25$ and $0-50$ as compared to 0-50 and 0-100 $\mathrm{m}$, respectively), when data from the nearshore stations $(1,5,10$ and 20nm) were pooled together ( $n=34$ and 32 , respectively). In the case of the offshore stations (40, 70 and 100 $\mathrm{nm})$, where only two depth ranges were sampled (0-50 and 0-100 m), the larvae were also more concentrated in the shallower depth range $(n=26$; $\mathrm{p}<0.05)$. Of the total number of stations (62) sampled, 9 stations had no or too few larvae in any of the depth ranges and a few others were not suitable for analysis with respect to low $\mathrm{DO}_{2}$ concentration because of no $\mathrm{DO}_{2}$ data (1), no low $\mathrm{DO}_{2}$ values at the depths sampled (2), $\mathrm{DO}_{2}$ values too low at the depths sampled (1), or the water column was too shallow to allow the sampling of more than one depth range (1). A total of 48 stations were finally used for the analysis and attention was focussed on the comparison of the abundances in two depth ranges, selected according to the location of the potentially limiting $\mathrm{DO}_{2}$ concentration.

After a preliminary analysis of the ratios of anchovy larvae abundances in the depth ranges sampled at each station and the $\mathrm{DO}_{2}$ concentration data, the abundance ratios were plotted against the depth of the $0.75 \mathrm{ml} \mathrm{O}_{2} \mathrm{I}^{-1}$ concentration at the corresponding stations; in the plots (Fig. 7A), the distances of the stations from the coast have also been identified. For this analysis, the data of 3 stations were not further considered because the actual sampling was from a depth which differed by more than $10 \%$ from the depth required (Table 3 ; ratios in parenthesis). Some of the ratios $(31 \%)$ had theoretically impossible values of less than 0.5 arising, presumably, from errors in the sampling and/ or counting procedures or from natural sampling variation. Most of these values lay in the range 0.25 to 0.5 . Ratios of $0.5 \pm 0.25$ were, therefore, regarded as falling within the error of the measurements and excluded when assessing the $\mathrm{DO}_{2}$ concentration that may be restricting the vertical movement of the anchovy larvae; only ratios equal to or higher than 0.75 were, thus, finally considered.

In Fig. 7a. seven of the stations with $\mathrm{B} / \mathrm{A}$ ratios higher than 0.75 and one station with a $\mathrm{C} / \mathrm{B}$ ratio higher than 0.75 were ultimately crucial in determining the limiting $\mathrm{DO}_{2}$ concentration. The depth range between the 1.0 and $0.5 \mathrm{ml} \mathrm{O}_{2} \mathrm{l}^{-1}$ concentrations is also shown for these 8 stations. It can be seen that, while the depths of the $1.0 \mathrm{ml} \mathrm{O}_{2}$ $1^{-1}$ concentration at 6 of the stations with $\mathrm{B} / \mathrm{A}$ ratios greater than 0.75 lay at or above $25 \mathrm{~m}$, the depths of the $0.75 \mathrm{ml} \mathrm{O}_{2} \mathrm{1}^{-1}$ isoline at 5 of the 7 stations lay, as required, below $25 \mathrm{~m}$. The depth of even the $0.5 \mathrm{ml}$ $\mathrm{O}_{2} 1^{-1}$ isoline for the station with a $\mathrm{C} / \mathrm{B}$ ratio greater than 0.75 was above $50 \mathrm{~m}$. However, allowing for a potential error of $\pm 10 \%$ in the measurements of the 
Table 3. Abundance of anchovy larvae (as density, in number $\mathbf{m}^{-3}$ ) off northern Chile during the 1995 winter, determined over 3 depth ranges: $\mathrm{A}(0-25 \mathrm{~m}), \mathrm{B}(\mathbf{0 - 5 0} \mathrm{m})$, and $\mathrm{C}(\mathbf{0 - 1 0 0} \mathrm{m})$. TRAN=transect $(\mathrm{Fig} .1)$; DIST=station's distance from the coast $(\mathrm{nm}) ; \mathrm{Z}-\mathrm{OX}=$ depth of the $0.75 \mathrm{ml} \mathrm{l}^{-1} \mathrm{O}_{2}$ concentration; $\mathrm{ND}=$ no data; (ratio)=depth of sampling $>10 \%$ lower than the fixed range; (expected abundance)=measured abundance because Z-OX was below $100 \mathrm{~m}$; $(*)=$ see results for explanation.

Tabla 3. Abundancia de larvas de anchoveta (como densidad, en número $\mathrm{m}^{-3}$ ) en la zona de Chile durante el invierno de 1995, determinada sobre 3 rangos de profundidad: A $(0-25), B(0-50 \mathrm{~m})$, and $\mathrm{C}(0-100 \mathrm{~m})$. TRAN=transecta (Fig. 1); DIST=distancia de la estación desde la costa ( $\mathrm{mn})$; Z-OX=profundidad de la concentración de $0.75 \mathrm{ml} \mathrm{l}^{-1} \mathrm{O}_{2} ; \mathrm{ND}=$ sin dato; (ratio)=profundidad de muestreo $>10 \%$ menor que el rango fijo; (expected abundance)=abundancia medida dado que $\mathrm{Z}$-OX fue mayor a $100 \mathrm{~m}$; $(*)=$ er resultados para explicación.

\begin{tabular}{|c|c|c|c|c|c|c|c|c|c|c|}
\hline \multirow[t]{2}{*}{ TRAN } & \multirow[t]{2}{*}{ DIST } & \multirow{2}{*}{$\begin{array}{l}\text { Time } \\
\text { (h) }\end{array}$} & \multirow{2}{*}{$\begin{array}{l}\mathrm{Z}-\mathrm{OX} \\
(\mathrm{m})\end{array}$} & \multicolumn{3}{|c|}{ Abundance } & \multicolumn{2}{|c|}{ Ratios } & \multirow{2}{*}{$\begin{array}{l}\text { Expected } \\
\text { abundance }\end{array}$} & \multirow{2}{*}{$\begin{array}{l}\text { Oxygen } \\
\text { limitation }\end{array}$} \\
\hline & & & & A & B & $\mathrm{C}$ & $\mathrm{B} / \mathrm{A}$ & $\mathrm{C} / \mathrm{B}$ & & \\
\hline \multirow[t]{4}{*}{1} & 5 & $7: 20$ & 24 & 1,01 & 1,81 & ND & 1,8 & & 4,10 & NO \\
\hline & 10 & $8: 20$ & 28 & 1,92 & 1,37 & 0,68 & 0,7 & & 2,37 & YES \\
\hline & 20 & $10: 20$ & 46 & 0,41 & 0,42 & 0,25 & & 0,6 & 0,55 & YES \\
\hline & 70 & $18: 40$ & 47 & ND & 0,41 & 0,85 & & 2,1 & 1,76 & NO \\
\hline \multirow[t]{5}{*}{3} & 1 & $4: 40$ & 45 & 4,35 & 3,72 & 1,27 & & $(0,3)$ & 2,24 & YES \\
\hline & 5 & $3: 30$ & 25 & 1,58 & 1,53 & 0,70 & 1,0 & & 2,76 & NO (*) \\
\hline & 10 & $1: 30$ & 28 & 3,47 & 4,14 & 2,23 & 1,2 & & 7,90 & $\mathrm{NO}(*)$ \\
\hline & 20 & $8: 00$ & 40 & 1,20 & 1,35 & 0,49 & & 0,4 & 1,23 & YES \\
\hline & 100 & $21: 00$ & 70 & 0,24 & 0,45 & 0,19 & & 0,4 & 0,26 & \\
\hline \multirow[t]{6}{*}{5} & 1 & 4:00 & 33 & 1,26 & 0,58 & ND & 0,5 & & 0,88 & YES \\
\hline & 5 & $2: 50$ & 28 & 0,36 & 0,28 & 0,15 & 0,8 & & 0,54 & NO \\
\hline & 10 & $1: 00$ & 63 & 0,67 & 0,47 & 0,39 & & 0,8 & 0,61 & NO \\
\hline & 20 & $8: 20$ & 60 & 0,17 & 0,21 & 0,04 & & 0,2 & 0,06 & YES \\
\hline & 40 & $12: 00$ & 59 & ND & 0,35 & 0,15 & & 0,4 & 0,24 & YES \\
\hline & 100 & $21: 30$ & 70 & ND & 2,81 & 3,27 & & 1,2 & 4,51 & YES \\
\hline \multirow[t]{6}{*}{7} & 1 & $4: 10$ & 26 & 0,88 & 0,49 & 0,27 & 0,6 & & 0,82 & YES \\
\hline & 5 & $2: 30$ & 31 & 0,58 & 0,20 & 0,07 & 0,3 & & 0,23 & YES \\
\hline & 10 & $0: 50$ & 45 & 0,79 & 0,82 & 0,14 & & 0,2 & 0,32 & YES \\
\hline & 20 & $8: 20$ & 60 & 0,46 & 0,46 & 0,16 & & 0,4 & 0,27 & YES \\
\hline & 40 & $15: 30$ & 94 & ND & 0,28 & 0,27 & & 1,0 & 0,28 & YES \\
\hline & 70 & $20: 20$ & 55 & ND & 6,20 & 3,66 & & 0,6 & 6,45 & YES \\
\hline \multirow[t]{5}{*}{9} & 1 & $6: 40$ & 22 & 0,76 & 1,12 & ND & $(1,5)$ & & 2,20 & NO \\
\hline & 5 & $5: 30$ & 53 & 2,67 & 2,94 & 1,82 & & $(0,6)$ & 2,68 & YES \\
\hline & 10 & $4: 00$ & 64 & 0,12 & 0,39 & 0,13 & & 0,3 & 0,20 & YES \\
\hline & 70 & $18: 50$ & 75 & ND & 3,99 & 4,40 & & 1,1 & 5,68 & YES \\
\hline & 100 & $0: 10$ & 64 & ND & 0,61 & 0,74 & & 1,2 & 1,14 & $\mathrm{NO}$ \\
\hline \multirow[t]{6}{*}{11} & 5 & 1:00 & 72 & 0,71 & 4,43 & 1,10 & & 0,3 & 1,52 & \\
\hline & 10 & $7: 10$ & 61 & 0,12 & 0,07 & 0,03 & & 0,4 & 0,05 & YES \\
\hline & 20 & $9: 40$ & 100 & 0,26 & 0,63 & 0,53 & & 0,8 & 0,53 & YES \\
\hline & 40 & $13: 10$ & 95 & ND & 0,39 & 0,21 & & 0,5 & 0,22 & \\
\hline & 70 & 18:00 & 90 & ND & 0,57 & 0,43 & & 0,8 & 0,45 & $\mathrm{NO}$ \\
\hline & 100 & $22: 30$ & 87 & ND & 2,70 & 0,86 & & 0,3 & 0,94 & \\
\hline \multirow[t]{6}{*}{13} & 1 & $4: 00$ & 63 & 1,98 & 0,87 & 0,21 & & 0,2 & 0,33 & YES \\
\hline & 5 & $2: 20$ & 59 & 0,26 & 0,53 & 0,26 & & 0,5 & 0,43 & YES. \\
\hline & 10 & $0: 30$ & 34 & 1,25 & 0,75 & 0,44 & 0,6 & & 1,28 & YES \\
\hline & 40 & $12: 00$ & 90 & ND & 0,57 & 1,13 & & 2,0 & 1,25 & YES \\
\hline & 70 & $16: 50$ & 92 & ND & 0,69 & 0,83 & & 1,2 & 0,89 & YES \\
\hline & 100 & $21: 30$ & 109 & ND & 1,17 & 1,36 & & 1,2 & $(1,36)$ & YES \\
\hline \multirow[t]{4}{*}{15} & 5 & $2: 10$ & 30 & 0,44 & 0,76 & 0,41 & 1,7 & & 1,37 & NO $(*)$ \\
\hline & 10 & $0: 50$ & 26 & 3,00 & 0,41 & 0,19 & 0,1 & & 0,69 & YES \\
\hline & 70 & $17: 00$ & 85 & ND & 2,70 & 0,76 & & 0,4 & 0,86 & \\
\hline & 100 & $21: 50$ & 120 & ND & 0,19 & 0,50 & & 2,6 & $(0,50)$ & YES \\
\hline \multirow[t]{6}{*}{17} & 1 & $5: 30$ & 27 & 3,43 & 3,28 & ND & 1,0 & & 6,03 & NO \\
\hline & 5 & $4: 10$ & 28 & 5,67 & 6,40 & 1,40 & 1,1 & & 4,99 & $\mathrm{NO}(*)$ \\
\hline & 10 & $2: 30$ & 50 & 5,24 & 4,86 & 2,29 & & 0,5 & 4,34 & YES \\
\hline & 20 & $8: 20$ & 76 & 4,91 & 4,38 & 3,88 & & 0,9 & 5,08 & YES \\
\hline & 40 & $12: 00$ & 125 & ND & 8,35 & 4,29 & & 0,5 & $(4,29)$ & \\
\hline & 100 & $20: 10$ & 80 & ND & 0,34 & 0,28 & & 0,8 & 0,33 & YES \\
\hline
\end{tabular}


depths of the iso-oxylines, the data for the 8 crucial stations were consistent with the view that a $\mathrm{DO}_{2}$ concentration of around $0.75 \mathrm{ml} \mathrm{O}_{2} \mathrm{l}^{-1}$ represented a barrier to the vertical movement of anchovy larvae. The rest of the data obtained could not be precisely related with this analysis as the depth ranges did not closely match the depth of the limiting $\mathrm{DO}_{2}$ concentration (no instantaneous graphical presentation of $\mathrm{DO}_{2}$ profiles to select the depths at each station).

Fig. 7b shows the relationship between temperature and the depth of the $0.75 \mathrm{ml} \mathrm{O}_{2} \mathrm{l}^{-1}$ concentration at each sampling station; for depths down to $75 \mathrm{~m}$, the average temperature corresponding to that limiting concentration was $13.55 \pm 0.35^{\circ} \mathrm{C}(\mathrm{n}=35)$. This is slightly higher than the value predicted from the temperature $-\mathrm{DO}_{2}$ regression (Table 1) but it was derived from a smaller set of data. Most of the temperatures where the depth of the limiting $\mathrm{DO}_{2}$ concentration was below $75 \mathrm{~m}$ were lower $\left(12.5^{\circ}-13^{\circ} \mathrm{C}\right)$ the above average, and corresponded to the most offshore stations ( $>20 \mathrm{~nm}$ from the coast), in the southern part of the area (Tocopilla-Antofagasta). To asses the possible influence of light conditions on the vertical distribution of anchovy larvae, the time of sampling at each station was considered (Table 3). These data showed that $55 \%$ of the $\mathrm{B} / \mathrm{A}$ ratios and $50 \%$ of the $\mathrm{C} / \mathrm{B}$ ratios calculated from the hauls made during the period between sunset and sunrise ( $c a$. 18:0006:00 h) exceeded 0.75 , the corresponding proportions for the daytime being, respectively, $50 \%$ and $36 \%$. The similary of the proportions for the hours of darkness and of light suggest that the vertical migration of anchovy larvae is not diurnal and that the results were not biased in this respect.

Based on the evidence that an oxygen barrier, in the vicinity of $0.75 \mathrm{ml} \mathrm{O}_{2} 1^{-1}$ could be limiting the vertical distribution of anchovy larvae, the whole of the abundance data (Tabla 3) subjected to a qualitative analysis. Since there were many pairs of data where the depth of the above concentrations was not close to the maximum depths of the ranges sampled, these depths were considered to vary by up to $\pm 30 \%$ of the actual values of the three depth ranges $( \pm 7.5 \mathrm{~m}$ down to $25 \mathrm{~m}, \pm 15 \mathrm{~m}$ down to $50 \mathrm{~m}$, and $\pm 30 \mathrm{~m}$ down to $100 \mathrm{~m}$ ). Although this variation is high, the vertical changes in abundance within a $100 \mathrm{~m}$ water column may, at least, suggest that such an oxygen limitation exists. The following results were considered to indicate that low $\mathrm{DO}_{2}$ concentrations limit the vertical distribution of anchovy larvae (Table 3); a) at 20 stations, the density was higher at the corresponding shallower depth range when the depth of the $0.75 \mathrm{ml} \mathrm{O}_{2} \mathrm{l}^{-1}$ concentration appeared within that depth range (025 or $0-50 \mathrm{~m}$ ), and b) at 8 stations, the abundance was similar $(<20 \%$ difference) for the two depth ranges when the depth of the $0.75 \mathrm{ml} \mathrm{O}_{2} \mathrm{l}^{-1}$ concentration appeared within the deeper depth range $(0-50$ or $0-100 \mathrm{~m})$. The abundance data at 12 of the remaining stations provided no evidence of limitation (similar abundances), at least at the depths compared, while in 8 other cases, the data were not clearly comparable. That is, within a set of $40 \mathrm{com}-$ parable data, $70 \%$ of them were consistent with the limitation hypothesis.

Most of the data $(75 \%)$ where the pairs of abundance values were similar even though the depth of the $0.75 \mathrm{ml} \mathrm{O}_{2} \mathrm{l}^{-1}$ concentration was closer to the shallower depth range, were from the most nearshore stations $(1,5$, and/or $10 \mathrm{~nm})$, where mixing by coastal upwelling may have influenced the larval distribution. Furthermore, in 4 of these cases (marked with an asterisk in Table 3), where the $0.75 \mathrm{ml} \mathrm{O}_{2} \mathrm{l}^{-1}$ concentration was considered to be below $25 \mathrm{~m}$ depth (Fig. 7a), the abundance was also sampled at the deeper depth range $(0-100 \mathrm{~m})$ and was found to be relatively lower than in the two upper depth ranges (Table 3 ).

In view of this evidence for low $\mathrm{DO}_{2}$ limitation of the vertical distribution of anchovy larvae, the potential bias in the estimation of larval density (number $\mathrm{m}^{-3}$ ), using a standard depth, was assessed. Expected abundance values (Table 3) were calculated, using the larval data for the standard depth range (0-100 $\mathrm{m}$ or shallower where necessary) and the depth of the $0.75 \mathrm{ml} \mathrm{O}_{2} \mathrm{l}^{-1}$ concentration to correct for the potential volume of water that would have contained the number of anchovy larvae recorded. Eighteen of the 20 stations supporting the hypothesis of $\mathrm{DO}_{2}$ limitation (Table 3), with higher abundances of larvae in the shallower depth range in association with the occurrence of the $0.75 \mathrm{ml} \mathrm{O}_{2}$ $1^{-1}$ cocentration in that depth range, had measured abundances that were similar to or higher than the expected abundance. On this basis, data on the abundance of anchovy larvae, expressed as number $\mathrm{m}^{-3}$, obtained during previous ichthyoplankton surveys off northern Chile, can thus be corrected 

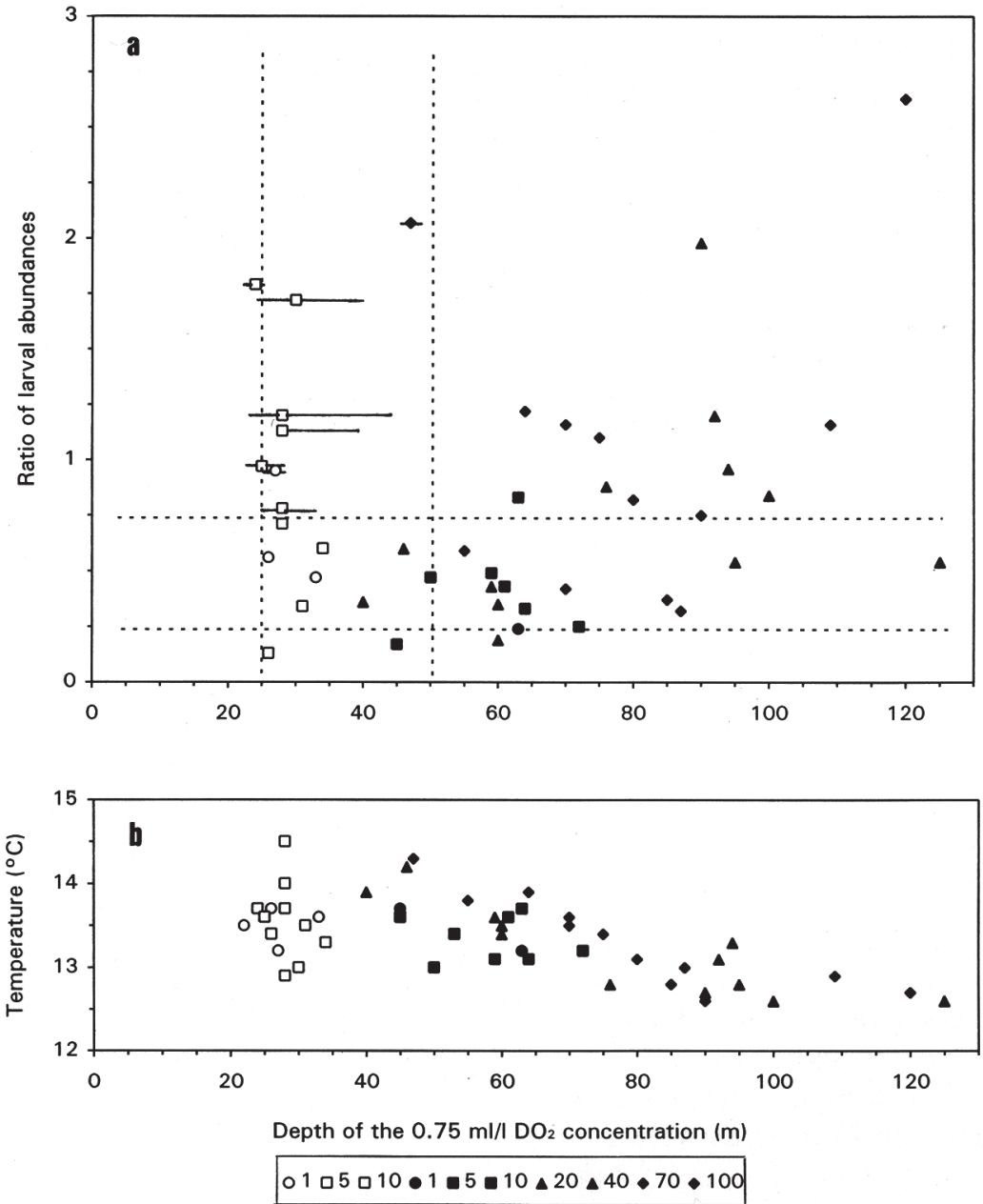

Figure 7. Depth of the $0.75 \mathrm{ml} \mathrm{O}_{2} \mathrm{l}^{-1}$ concentration during the 1995 winter cruise plotted against the ratio of the abundances of anchovy larvae at two depth ranges in the same station (a) and the corresponding temperature at that dissolved oxygen concentration (b). Ratios as in Table 3: B/A (open symbols) and C/B (closed symbols); the shape of the symbols represent distances from the coast $(\mathrm{nm})$ of the stations. In 7a, the dotted lines correspond to the margin of error $( \pm 0.25)$ assumed around the hypothetical ratio of 0.5 (horizontal lines) and the 25 and 50 m depths (vertical lines); the horizontal bars crossing some of the symbols (the critical ones) indicate the depth range between $1.0 \mathrm{ml} \mathrm{O}_{2} \mathrm{l}^{-1}$ (to the left) and $0.5 \mathrm{ml} \mathrm{O}_{2} \mathrm{l}^{-1}$ (to the right) concentrations.

Figura 7. Profundidad de la concentración de $0.75 \mathrm{ml} \mathrm{O}_{2} \mathrm{l}^{-1}$ durante el invierno de 1995, ploteada con la proporción de las abundancias de larvas de anchoveta de dos de los rangos muestreados en la misma estación (a) y la correspondiente a la Tabla 3: B/A (símbolos abiertos) y C/B (símbolos cerrados); la forma de los símbolos representa las distancias desde la costa $(\mathrm{mn})$ de las estaciones. En 7a, las líneas punteadas corresponden al margen de error $( \pm 0.25)$ supuesto alrededor de la proporción hipotética de 0.5 (líneas horizontales) y las profundidades de 25 y $50 \mathrm{~m}$ (líneas verticales); las barras horizontales que cruzan algunos de los símbolos (los críticos) indican el rango de profundidad entre las concentraciones de $1.0 \mathrm{ml} \mathrm{O}_{2} \mathrm{I}^{-1}$ (a la izquierda) y $0.5 \mathrm{ml} \mathrm{O}_{2}$ $\mathbf{l}^{-1}$ (a la derecha). 
for limitation by the $\mathrm{DO}_{2}$ barrier. On the order hand, in 3 stations (Table 3), this low $\mathrm{DO}_{2}$ barrier was located below $100 \mathrm{~m}$, and during the 1990-95 winter period, this situation ocurred mainly in the most southerly part of the stuydy area (Fig. 5), with the exception of 1991. In summary, the anchovy larvae off northern Chile appear quite frequently to be limited to depths of less than $100 \mathrm{~m}$ due to low $\mathrm{DO}_{2}$ concentrations.

\section{DISCUSSION}

The oceanographic conditions off northern Chile are highly characteristic of eastern boundary systems, with the presence of wind-driven coastal upwelling and of numerous filaments and eddies within the coastal zone (Fonseca \& Farías, 1987; Barbieri et al., 1995). This area has been described as one of low amplitude seasonal cycles, with persistent upwelling and relatively low pigment concentration throughout the year (Thomas et al., 1994). Nevertheless, data on seasonal surface temperature distribution has shown a pattern of warm months (November-April) and cold months (JulySeptember), with a more homogenous distribution of temperature during the winter (Yañez et al., 1995). Also, the area is under the influence of interannual warm and cold events, resulting in strong temporal and spatial variability in the environment and in widely fluctuating fisheries yields of clupeids (Alheit \& Bernal, 1993; Yañez et al., 1995).

The present results on the distributions of surface temperature and surface salinity during the winters of 1990 to 1995 indicated a sequence from cooler (1990) to warmer (1992-93) and back to cooler (1995) conditions in the area off northern Chile. These data, gathered from quasi-synoptic oceanographic cruises, concur with results obtained by Yañez et al. (1995) during the period 1987-92, based on satellite observations of surface temperature, indicating a sequence from warm, moderate El Niño conditions (1987) to cold (1990) and then back to warm, moderate El Niño conditions (1992). Given that the area of study is characterized by a high degree of cloud cover, especially during winter (Thomas et al., 1994; Barbieri et al., 1995), and that ship-data are limited with respect to the scales of spatio-temporal sampling, the agreement between these results provided a good validation of data obtained with two different methodologies.

Moreover, regional climate reports (BAC 1994, 1996), including mean monthly surface temperature at a coastal station off Arica and time series of the SOI support, in general terms, the results obtained in this study.

The results of this study indicated that the abundance of anchovy larvae off northern Chile varied significantly between the 1990-95 winter periods. The greatest values were found during 1994, representing the transition between the 1992 warm event and the colder condition of 1995, whereas the lowest values were observed during 1991, the transition between the 1990 cold condition (started in 1988, Yañez et al., 1995) and the 1992 warm event. Overall, the warmer conditions initiated during 1992 appeared to have provided a more suitable environment for the survival and feeding of anchovy larvae in the area, whereas changes in the distribution of low oxygen concentrations did not appear to have had a direct influence on larval abundance and distribution. Previously, Loeb \& Rojas (1988), analysing a 10 year sequence (196483) of ichthyoplankton sampling off northern Chile, found no significant correlation between anchovy egg and larvae abundances and temperature or salinity. Also, these authors reported higher anchovy abundances during years inmediately following El Niño (1966, 1973), the 1972 El Niño, and during a cold year (1970).

An important limitation in the comparison of larval abundances between different years is that sampling time may not match the time of highest abundance. This is the case of the present study, based on IFOP cruises primarily designed to monitor spawning stocks and reproductive activity. Specifically, the winter cruises of 1990 and 1991 were carried out earlier (July-August and August, respectively) than the subsequent cruises (AugustSeptember during 1992 to 1995). On the other hand , the time of maximum reproductive activity during the winter probably varies in relation to cold and warm years. The comparisons made here could be validated with or supported by related data from the 1990-95 sequence, such as, the annual abundance of anchovy larvae, the abundance of eggs during the winter cruises, the biomass of anchovy stocks during winter and/or anchovy annual landings in the area of study.

Data on the integrated abundance of anchovy eggs (number/10m²), for the 1990-95 winter period 
off northern Chile (Table 4), indicate that the mean abundances for the different winters (considering the whole of the stations sampled), were similar between 1991, 1992, 1993 and 1995, but about 3040\% higher during 1990 and roughly 3 times higher during 1994 (IFOP, unpublished report). Also, data on the winter biomass of spawning anchoveta off northern Chile (Table 4), using hydro-acoustic methods, indicated that the values were at least an order of magnitude higher during 1994 compared with the rest of the years $(<300$ thousand $t)$ of the 1990-95 sequence (IFOP, unpublished report). Overall then, the significantly higher mean value of anchovy larvae during the winter of 1994, within the 1990-95 sequence, appears to represent a true difference whereas the variation between the other years is less well defined.

In terms of anchovy landings within the area of this study (Table 4), official statistics (SERNAP, Chile) indicated that 1994 was the year of highest landings within the 1990-95 sequence, whilst the lowest values were observed during 1990 and 1991. In comparing the influence of cold and warm years on the annual landings of anchovy stocks off northern Chile during the 1987-92 sequence, Yañez et al., (1995) reported the lowest landings during the 1987 moderate El Niño, intermediate values during the colder years of 1988, 1990 and 1991, and higher values during 1989 and 1992. Altogether, there appears to be no simple, direct relationship between warm and cold conditions and anchovy abundance, in terms of landings, spawning biomass, larval stages and eggs, although over a longer sequence of analysis, anchovy landings have been reported to be usually the lowest during warm El Niño conditions but recover quickly after these events (Alheit \&Bernal, 1993).

With respect to the spatial distribution of anchovy, the present results indicated that the larvae were mainly concentrated within the most nearshore areas ( $5 \mathrm{~nm}$ from the coast), independent of the oceanographic conditions, although the higher abundances extended to the offshore area during the winters of 1993 to 1995 , significantly so during 1995. Also, off Arica, the northern limit of the study area, the larvae were frequently distributed further offshore, perhaps due to the protective effect of the large embayment formed between Peru and Chile

Table 4. Estimates of the abundances of anchovy eggs and adults off northern Chile, for the 1990-95 period. Egg abundances were obtained from the same integrated hauls $(0-100 \mathrm{~m})$ as for the larval samples of the present study and are the means of all stations sampled. The adult biomasses are expressed as winter direct estimates, obtained from hydroacoustical methods during the same cruises considered in the present study (IFOP Hydroacoustic Project Reports, 1996). The total annual landings of anchovy caught off northern Chile were derived from the SERNAP Statistical Report (1995).

Tabla 4. Estimaciones de las abundancias de huevos de anchoveta y de adultos en la zona norte de Chile, para el período 1990-95. Las abundancias de huevos fueron obtenidas durante los mismos lances integrados (0-100 m) utilizados para las muestras de larvas del presente estudio y representan el promedio de todas las estaciones muestreadas. Las biomasas de adultos están expresadas como estimaciones invernales directas, obtenidas por métodos hidroacústicos durante los mismos cruceros del presente estudio (IFOP Informes Proyectos Hidroacústicos, 1996). Los desembarques anuales totales de anchoveta capturada en la zona norte de Chile fueron derivados del Anuario Estadístico de SERNAP (1995).

\begin{tabular}{|c|ccc|}
\hline Year & $\begin{array}{c}\text { Winter egg } \\
\text { abundance } \\
\left.\text { (number/10m }{ }^{2}\right)\end{array}$ & $\begin{array}{c}\text { Winter adult } \\
\text { biomass } \\
\text { (thousands of tons) }\end{array}$ & $\begin{array}{c}\text { Annual } \\
\text { landings } \\
\text { (thousands of tons) }\end{array}$ \\
\hline 1990 & 2863 & 68 & 609 \\
1991 & 2256 & 256 & 606 \\
1992 & 2072 & 113 & 992 \\
1993 & 1771 & 129 & 1169 \\
1994 & 6153 & 1376 & 2116 \\
1995 & 2225 & 296 & 1613 \\
\hline
\end{tabular}


(Fig. 1). This pattern of larval distribution is attributed in part to the mainly coastal distribution of adult anchovy $(<60 \mathrm{~nm})$, with further inshore concentrations during warm EL Niño conditions and an extension offshore during cold months and years (Jarre et al., 1991; Yañez et al., 1995).

For the Peruvian system, Jarre et al., (1991) established that the distribution of anchovy is mainly mediated by surface temperature although, in analysing the potential distribution volume of the stocks, they also imply the limitations imposed by low $\mathrm{DO}_{2}$ concentrations. However, the effect of low $\mathrm{DO}_{2}$ upon the small pelagic clupeids inhabiting the Chile- Peru Current System has not previously been evaluated in terms of explaining interannual and/or mesoscale variability in their abundance, distribution, or recruitment strength. The results of the present study suggested the ocurrence of a barrier to the vertical distribution of anchovy larvae, determined by a concentration of $c a .0 .75 \mathrm{ml} \mathrm{O}_{2} 1^{-1}$. Although it was not possible to distinguish clearly between the effects of temperature and $\mathrm{DO}_{2}$ because of the high correlation between these two variables, the limiting concentration above suggested that the base of the thermocline $\left(15^{\circ} \mathrm{C}\right)$ may not, in fact, constitute their main barrier, since $\mathrm{DO}_{2}$ concentrations between 3 and $4 \mathrm{ml} \mathrm{l}^{-1}$ are associated with it (Table 1).

The lack of information about the effect of low $\mathrm{DO}_{2}$ concentrations on the distribution of anchovy larvae contrast with that available from several studies on zooplankton distribution in relation to $\mathrm{DO}_{2}$ content in eastern boundary currents. Longhurst (1967) found high abundances of zooplankton, predominantly the resting stages of Calanus helgolandicus, in the oxygen minimum layer of the California current, at concentrations down to $0.2 \mathrm{ml}$ $\mathrm{O}_{2} \mathrm{l}^{-1}$. An even lower value of $0.1 \mathrm{ml} \mathrm{O}_{2} \mathrm{l}^{-1}$ was considered by Judkins (1980) to limit the vertical distribution of zooplankton off Peru. Other reports for the waters off Peru indicated that small copepods (Oncaeidae, Oithonidae and small calanoids) were apparently restricted to the top $30 \mathrm{~m}$, or above the $0.5 \mathrm{ml} \mathrm{l}^{-1}$ iso-oxyline, both during the day and the night (Sameoto, 1981; Smith et al., 1981). Santander et al., (1981) found that, although there were indications of the limitation of vertical migration of zooplankton starting at $0.5 \mathrm{ml} \mathrm{O}_{2} \mathrm{l}^{-1}$, the concentration of $0.2 \mathrm{ml} \mathrm{O}_{2} \mathrm{l}^{-1}$ was that ultimately presenting a barrier to downward movement. Boyd et al. (1980) reported that there were specific differences in oxygen tolerance off Peru, where Calanus chilensis appeared only in water containing more than $0.8 \mathrm{ml} \mathrm{O}_{2} \mathrm{1}^{-1}$, while Centropages brachiatus was restricted by concentrations of only about $0.2 \mathrm{ml} \mathrm{O}_{2} 1^{-1}$.

Elsewhere, there are few other studies of the effect of $\mathrm{DO}_{2}$ upon the distribution and abundance of marine zooplankton. In Lindaspollen (Norway), Lie et al. (1983) observed the presence of Sagitta elegans and Aglanthe digitale at $\mathrm{DO}_{2}$ concentrations of $0.5 \mathrm{ml} \mathrm{l}^{-1}$ and, more recently, Roman et al. (1993) showed experimentally that Acartia tonsa and Oithona calcarva had lower survival rates at $1 \mathrm{mg}$ $(=0.7 \mathrm{ml}) \mathrm{O}_{2} 1^{-1}$, in accord with observations that, in Chesapeake Bay, copepods and nauplii of these species were in low abundances in, or absent from, water containing this $\mathrm{DO}_{2}$ concentration. Altogether the results from the studies on marine zooplankton distribution and $\mathrm{DO}_{2}$ content are in reasonable agreement with the possibility that the downward vertical migration of anchovy larvae off northern Chile is rectricted by their inability to tolerate $\mathrm{DO}_{2}$ concentrations below about $0.75 \mathrm{ml} \mathrm{l}^{-1}$.

The fact that off northern Chile, and probably also off Peru, the upper boundary of the oxygen minimum layer is found at relatively shallow depths $(<100 \mathrm{~m})$ in the coastal zone and that anchovy populations tend to concentrate within the nearshore area $(<60 \mathrm{~nm})$ and are vertically limited by low oxygen concentrations, adds a further complexity to the interpretation of the patterns of abundance and distribution of anchovy, and other pelagic resources, as compared with similar eastern boundary systems. In this sense, the much higher fisheries yields of clupeids in the Humboldt Current System may in part be explained by higher availability within the surface layers due to a compression of their inhabited volume, as well as by a narrower shelf, as compared to other systems.

A deeper understanding of the dynamics of the anchovy populations exploited off northern Chile and within the Humboldt Current System, based on the analyses of their patterns of migration and associated oceanographic conditions on a regional scale, are now required in order to asses the sustainability of this highly variable and highly vulnerable resource. 


\section{ACKNOWLEDGEMENTS}

This study was supported by a FONDECYT project $\mathrm{N}^{\circ}$ 1950043-1995 assigned to C.E. Morales, M. Braun, O. Rojas and H. Reyes. Also, J.L. Blanco and $\mathrm{M}$. Braun were supported by a FIP project $\mathrm{N}^{\circ} 95$ 03. Authorization for using data derived from FIP projects $\mathrm{N}^{\circ}$ 93-01, 94-13 and 95-03, property of and financed by the Fondo de Investigación Pesquera, is acknowledge to the Consejo de Investigación Pesquera (Chile). This study is a contribution to the JGOFS- Chile Programme (1994-97).

\section{REFERENCES}

Alheit, J.\& P. Bernal. 1993. Effects of physical and biological changes on the biomass yield of the Humboldt Current System. In: Large Marine Ecosystems. K. Sherman, L. Alexander \& B. Gold (Eds.), Am. Assoc. Adv. Sci. Press, Washington DC, pp. 53-68.

BAC. 1994. Boletín de alerta climático: diciembre. Comisión Permanente del Pacífico Sur, №51, 8 pp.

BAC. 1996. Boletín de alerta climático: noviembre.Comisión Permanente del Pacífico Sur, $\mathrm{N}^{\circ} 74,9$ pp.

Bakun,A. 1989. Recruitment in fishery resources and its relationship to environment: accesible pathways to greater insight. Rev. Pacífico Sur (CPPS), Número Especial, pp. 25-34.

Barbieri, M.A., M. Bravo, M. Farías, A. González, O. Pizarro \& E. Yañez, E. 1995. Fenómenos asociados a la estructura térmica superficial del mar observados a través de imágenes satelitales en la zona norte de Chile. Invest. Mar., Valparaíso, 23: 99-122.

Bernal, P., F. Robles \& O. Rojas. 1992. Variabilidad física y biológica en la región meridional del sistema de corrientes Chile-Perú. Monografías Biológicas, Fac. Cs. Biológicas, P. Univ. Católica de Chile, J.C. Castilla (Ed.), $\mathrm{N}^{\circ}$ 2: 75-102.

Blanco, J.L. \& M. Díaz. 1985. Caracerísticas oceanógraficas y desarrollo de El Niño 1982-83 en la zona norte de Chile. Invest. Pesq. (Chile), 32: 53-60.
Boyd, C.M., S.L. Smith \& T.J. Cowles. 1980. Grazing patterns of copepods in the upwelling system off Peru. Limnol. Oceanogr., 25: 583-596.

Fonseca, T. \& M. Farías. 1987. Estudio del proceso de surgencia en la costa chilena utilizando percepción remota. Invest. Pesq. (Chile), 34: 33-46.

Hutchings, L. 1992. Fish harvesting in a variable productive environment-Searching for rules or searching for exceptions. S. Afr. J. mar. Sci., 12: 297-318.

Jarre, A., P. Muck, D. Pauly. 1991. Two approaches for modelling fish stock interactions in the Peruvian upwelling ecosystem. ICES, Mar. Sci. Symp., 193: 171-184.

Judkins, D.C. 1980. Vertical distribution of zooplankton in relation to the oxygen minimum off Peru. Deep-Sea Res., 27ª : 475-487.

Kawasaki, T. 1991. Long-term variability in the pelagic fish populations. In: Long-term variability of pelagic fish populations and their environment. T. Kawasaki, S. Tanaka, Y. Toba \& A. Taniguchi (Eds.), Pergamon Press, pp. 47-60.

Le Clus, F. 1991. Hydrographic features related to pilchard and anchovy spwaning in the northern Benguela system, comparing three environmental regimes. S. Afr. J. mar. Sci., 10: 103-124.

Lie, U., T. Magnesen, B. Tunberg \& D.L. Aksnes. 1983. Preliminary studies on the vertical distribution of size-fractions in the zooplankton community in Lindaspollene, western Norway, Sarsia, 68: 65-68.

Lluch-Belda, D., D. Lluch-Cota, S. Hernández. C. Salinas \& R.A. Schwartzlose. 1991. Sardine and anchovy spwaning as related to temperature and upwelling in the California Current System. Rep. Calif. Coop. Oceanic Fish. Invest., 32: 105-111.

Lluch-Belda, D., R.A. Schwartzlose, R. Serra, R. Parrish, T. Kawasaki, D. Hedgecock \& R.J.M. Crawford. 1992. Sardine and anchovy regime fluctuations of abundance in four regions of the world oceans: a workshop report. Fish. Oceanog., 1: 339-347.

Loeb, V. \& O. Rojas. 1988. Interannual variation of ichthyoplankton composition and abundance 
relations off northern Chile, 1964-83. Fish. Bull., U.S., 85: 1:24.

Longhurst, A.R. 1967. Vertical distribution of zooplankton in relation to the eastern Pacific oxygen minimum. Deep-Sea Res., 14: 51-63.

Morales, C.E., J.L. Blanco, M. Braun, H. Reyes \& N. Silva. 1996. Chlorophyll-a distribution and associated oceanographic conditions in the upwelling region off northern Chile during the winter and spring 1993. Deep-Sea Res., 43: 267289.

Richman, J.G. \& S. Smith. 1981. On the possible enhancement of oxygen depletion in the coastal waters of Peru between $6^{\circ}$ and $11^{\circ} \mathrm{S}$. Bol. Inst. Mar Perú. Vol. Extr., pp. 22-33.

Robles, F., E. Alarcón \& A. Ulloa. 1976. Water masses in the northern chilean zone and their variations in the cold period (1967) and warm periods (1969, 1971-1973). FAO Fish. Rep., 185, pp. 94-196.

Roman, M.R., A.L. Gauzens, W.K. Rhinehart \& J.W. White. 1993. Effects of low oxygen waters on Chesapeake Bay zooplankton. Limnol. Oceanogr., 38: 1603-1614.

Sameoto, D. 1981. Distribution and abundance of six species of fish larvae in Peruvian waters and their relationship with the physical and biological environment. Bol. Inst. Mar Perú, Vol. Extr., pp. 171-179.

Santander, H., S. Carrasco \& G. Luyo. 1981. El zooplankton del área norte del Perú. Bol. Inst. Mar Perú, Vol. Extr., pp. 244-253.

Santander, H. \& R. Flores. 1983. Los desoves y distribución larval de cuatro especies pelágicas y sus relaciones con las variaciones del ambiente marino frente al Perú. FAO Fish. Rep., (291) Vol. 3, pp. 835-867.

SERNAP. 1994-95. Anuario estadístico de pesca. Servicio Nacional de Pesca. Ministerio de Economía, Chile, 240 pp.
Serra, R. 1983. Changes in the abundance of pelagic resources along the Chilean coast. FAO Fish. Rep., (291) Vol. 2, pp. 255-284.

Sievers, H. \& N. Silva. 1982. Masas de agua y circulación geostrófica frente a la costa de Chile, latitudes $18^{\circ} \mathrm{S}$ y $33^{\circ} \mathrm{S}$. Cienc. Téc. Mar, CONA 6: 61 99.

Silva, N. 1983. Masas de agua y circulación en la región del norte de Chile, latitudes $18^{\circ} \mathrm{S}-32^{\circ} \mathrm{S}$ (Operación Oceanográfica Mar Chile XI- ERFEN II). Cienc. Téc. Mar, CONA 7: 47-84.

Smith, P.S., Boyd \& P.V. Lane. 1981. Short-term variations in the vertical distribution of copepods off the coast of northern Peru. Bol. Inst. Mar Perú, Vol. Extr., pp. 112-118.

Smith, P. \& S. Richardson. 1979. Técnicas standard para prospecciones de huevos y larvas de peces. FAO Fish. Tech. Pap., 175, pp. 100.

Thomas, A., T. Strub, F. Huang \& C. James. 1994. A comparison of the seasonal and interannual variability of phytoplankton pigment concentrations in the Peru and California Current systems. J. Geophys. Res., 99: 7355-7370.

Yáñez, E. 1989. Fluctuaciones de los principales recursos pelágicos explotados en la zona norte de Chile y variaciones ambientales asociadas. Rev. Pacífico Sur (CPPS), Número Especial , pp. 509520.

Yáñez, E. 1991. Relationship between environmental changes and fluctuating major pelagic resources exploited in Chile (1959-1988). In: Long-term variability of pelagic fish populations and their environment. T. Kawasaki, S. Tanaka, Y. Toba \& A. Tanigushi (Eds.), Pergamon Press, pp. 301-309.

Yáñez, E., A. González \& M.A. Barbieri. 1995. Estructura térmica superficial del mar asociada a la distribución espacio-temporal de sardina y anchoveta en la zona norte de Chile entre 19871992. Invest. Mar., Valparaíso, 23: 123-147. 